\title{
A NEW SPECIES OF THE GENUS PHOEBE NEES (LAURACEAE) FROM NORTH-EAST INDIA
}

\author{
M. GANGOPADHYAY ${ }^{1}$ AND A. SARMAH ${ }^{2}$ \\ Central Botanical Laboratory, Howrah 711103, West Bengal, India
}

Key words: Lauraceae, New species, Phoebe

During the course of the study of the family Lauraceae, the authors came across some interesting specimens from Arunachal Pradesh, India housed in ASSAM (Herbarium of Botanical Survey of India, Eastern Circle, Shillong) and APFH (Herbarium of State Forest Research Institute, Itanagar, Arunachal Pradesh). Those were found to be of a new species of the genus Phoebe Nees which is described in this communication.

Phoebe hedgei M. Gangop. et A. Sarmah sp. nov.

(Plate 1)

Phoebe declinata (Blume) Nees affinis, sed differt foliis tenuibus chartaceis late oblongis, elliptico-oblongis vel raro ellipticis ad obovato-ellipticis, infra puberulis, infructescentiis simplicibus paniculatis.

Holotypus: Arunachal Pradesh, West Kameng District, Saddle - Sessa, 23.9.1997, Anupam Sarmah 4180 (APFH)

Paratypus: Arunachal Pradesh, Lohit District, Tweng village, ca 3,600 m, 23.12.1993, A.S. Chowhan 99495 (ASSAM).

Allied to Phoebe declinata (Blume) Nees, but differs in having thinly chartaceus broad oblong, elliptic-oblong or rarely elliptic to obovate-elliptic leaves, puberulus beneath and simple paniculate infructescences.

Tree, 4-5 m high. Branchlets slender, angled, yellowish to pale brown below, blackish above, 3-4 mm wide, inconspicuously ribbed and furrowed, glabrous, lenticellate; terminal buds narrow ovate-lanceolate, 3-3.5 × ca $1.5 \mathrm{~mm}$, acuminate, yellow pilosulus. Leaves alternate, thinly chartaceus, blackish brown above, paler beneath, broad oblong, elliptic-oblong or rarely elliptic to obovate-elliptic, $13-20 \times 4.2-5.8 \mathrm{~cm}$, obtuse or sometimes cuneate at base, slightly decurrent at extreme base, slightly incurved at margins, acuminate (acumens 5-10 mm long) at apex, glabrous above, finely appressed puberulus beneath; mid-vein slender, channeled above, raised beneath; lateral nerves 1112 pairs, slender, distant, arcuate, raised above, canaliculated beneath; tertiary nerves prominent, scalariform; minor nervules laxly reticulate, faint above, prominent beneath; petioles slender, 15-28 mm long, 1-1.5 mm wide, deeply concave above, shallowly

\footnotetext{
${ }^{1}$ Corresponding author. E-mail: mgangopadhyay55@rediffmail.com

${ }^{2}$ World Wildlife Fund (WWF), Tejpur, Assam. E-mail: anupamsarmah@gmail.com
} 


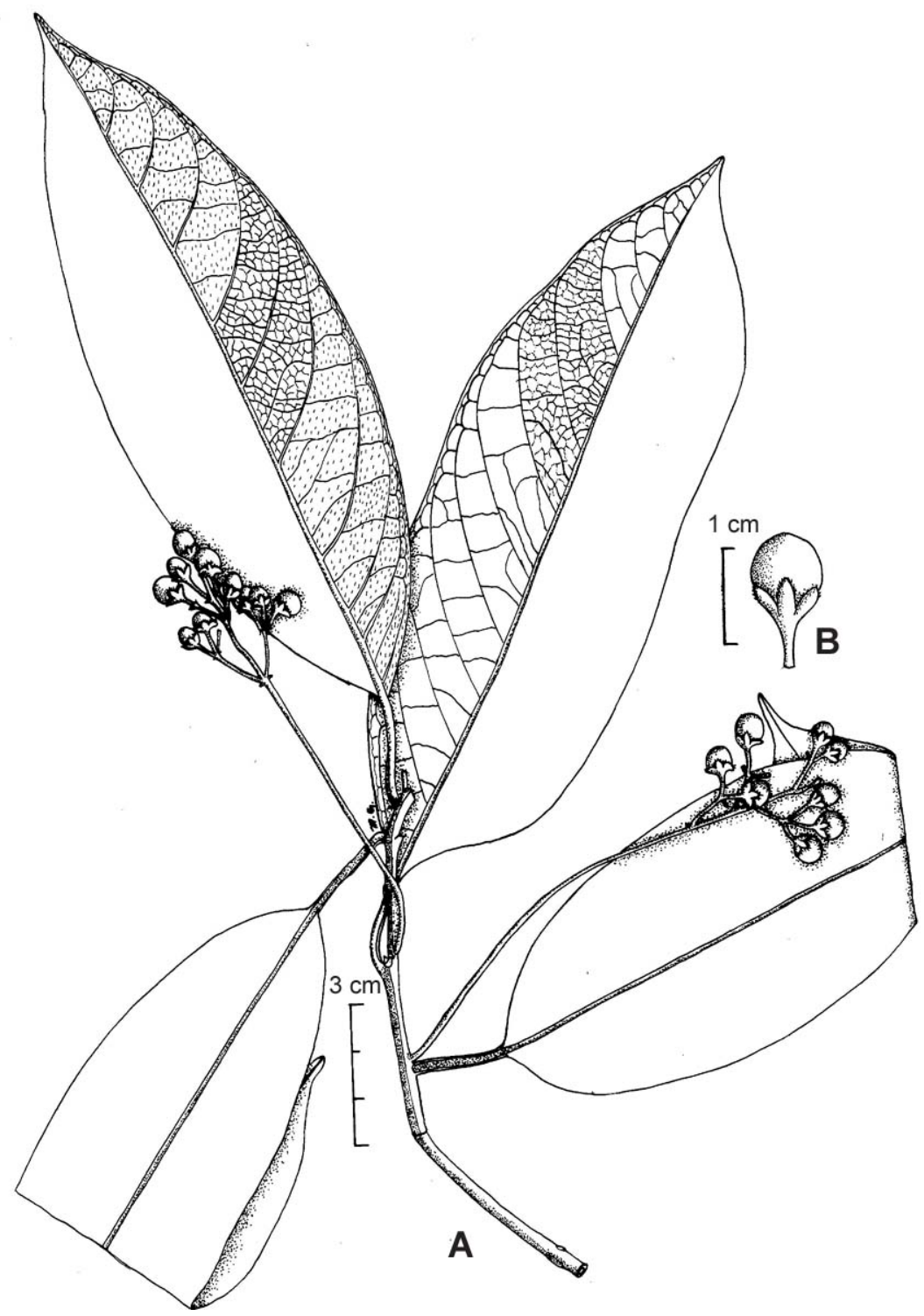

Plate 1. Phoebe hedgei M. Gangop. et A. Sarmah A. Branch with fruits; left hand upper: lower surface of leaf; left hand lower: upper surface of leaf; B. Fruit (after A. Sharma 4180).

winged at margins, blackish, glabrous. Flowers not seen. Infructescences paniculate, simple, 9-15 cm long, slender, glabrous; peduncles 6-10.5 cm long, ca $1 \mathrm{~mm}$ thick, flattened and angled. Fruits globose, 5.5-8 mm in diameter, greenish when young, blackish with age, scattered pustulate, glabrous; stalk slender, 5-8 mm long, ca $1 \mathrm{~mm}$ 
wide, thin, flat; tepals subindurate with semi-clasping lobes, ca $2.5 \times 1.5 \mathrm{~mm}$, yellow; lobes oblong, obtuse to subacute, glabrous above, ciliate at margins, sericeus within.

Distribution: India (Arunachal Pradesh).

Ecology: Scarce in evergreen forests at about 3,600 m altitude.

Fruiting: September - December.

Phoebe declinata has been recently reported by Gangopadhyay (2006) from Bangladesh in typical glabrous and sparsely pubescent forms. This new species is allied to the sparsely pubescent form of $P$. declinata in having globose fruits with semi-clasping tepal lobes but differs from it in having thinly chartaceus broad oblong, elliptic-oblong or elliptic to obovate-elliptic leaves and simple paniculate infructescences instead of coriacus, obovate, oblong-obovate to oblanceolate, 6-11.5 × 2.5-4 cm leaves and compound paniculate infructescences, respectively.

The specific epithet has been given in the honour of Dr. S.N. Hedge, Ex-Director, the State Forests Research Institute, Itanagar, Arunachal Pradesh.

\section{Acknowledgements}

Authors are grateful to the Director, the State Forests Research Institute, Itanagar, Arunachal Pradesh and the Deputy Director, Eastern Circle, Botanical Survey of India, Shillong for research facilities. Thanks are due to Dr. N.C. Majumdar, Retired Scientist, Botanical Survey of India, for the Latin translation.

\section{Reference}

Gangopadhyay, M. 2006. Notes on the family Lauraceae from India and its adjoining countries - I. Bulletin of Botanical Survey of India 48(1-4): 103-156. 